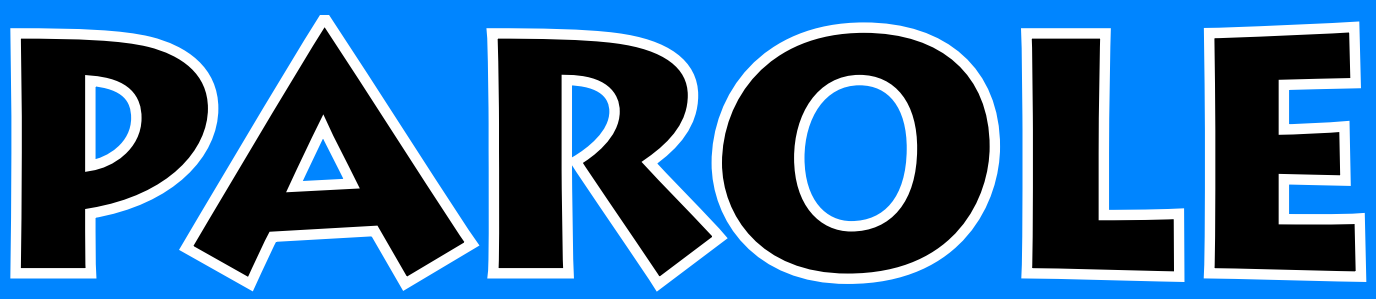

\title{
Journal of Linguistics and Education
}

\author{
Volume 8 Number 2 October 2018
}

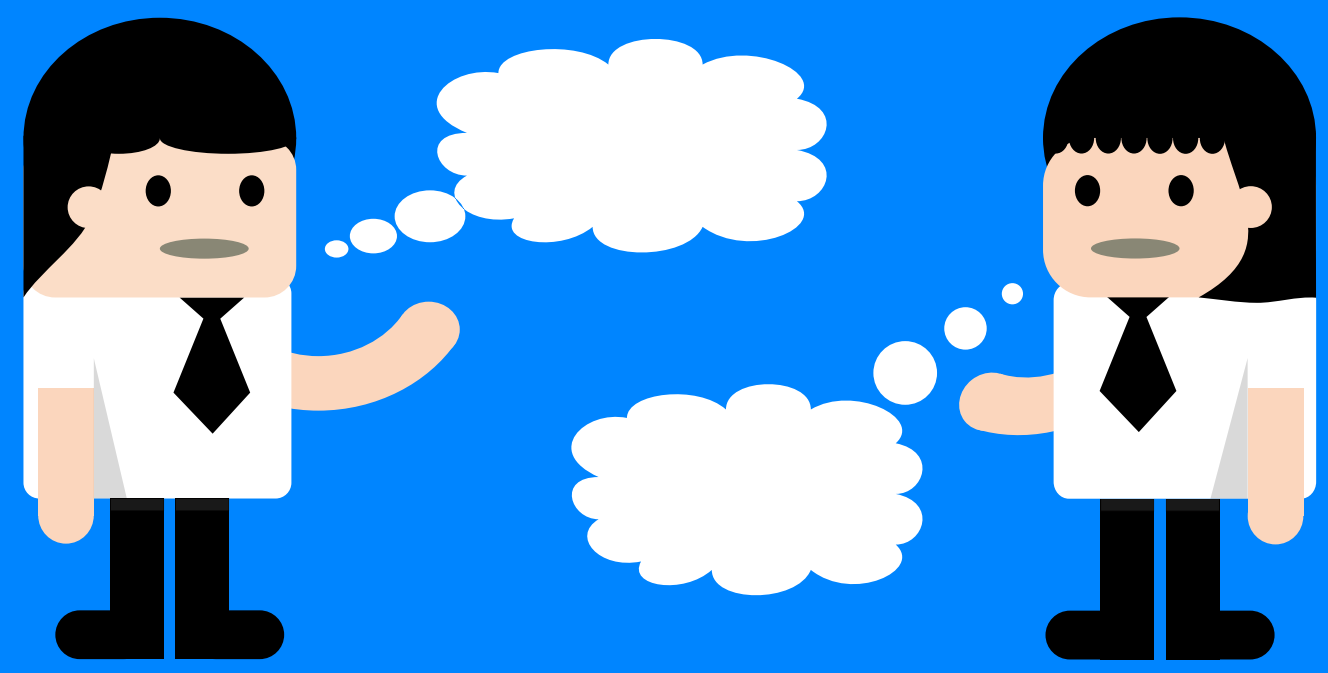

Master Program in Linguistics

Diponegoro University 


\title{
Parole Journal of Linguistics and Education
}

\author{
Volume 8 Number 2 October 2018
}

Available online at: http://ejournal.undip.ac.id/index.php/parole

\section{Editorial Team}

Editor in Chief:

Deli Nirmala, Diponegoro University, Indonesia

\section{Editorial Boards:}

Agus Subiyanto, Diponegoro University, Indonesia

I Wayan Pastika, Udayana University, Indonesia (ScopusID: 57191869693)

Jozina Vander Klok, University of Oslo, Norwegia (ScopusID: 55957791300)

Ketut Artawa, Udayana University, Indonesia (ScopusID: 57191382985)

Nurhayati, Diponegoro University, Indonesia (ScopusID: 57195940976)

Suharno, Diponegoro University, Indonesia

Yudha Thianto, Trinity Christian College, USA (ScopusID: 57200093139)

\section{Reviewers:}

Dwi Wulandari, Diponegoro University, Indonesia

George Jacobs, James Cook University, Singapore (ScopusID: 7203023838)

Helena I.R. Agustin, Semarang State University, Indonesia

Herudjati Purwoko, Diponegoro University, Indonesia

John H. Jack Rouzer, Ohio State University, USA

Joko Kusmanto, Politeknik Negeri Medan, Indonesia

Mukhlash Abrar, Jambi University, Indonesia

Mukhlis Abu Bakar, National Institute of Education, Singapore (ScopusID: 57200632151)

Mytha Candria, Diponegoro University, Indonesia

Peter Suwarno, Arizona State University, USA

Rin Surtantini, Pusat Pengembangan dan Pemberdayaan Pendidik dan Tenaga Kependidikan (PPPPTK) Seni dan Budaya Yogyakarta, Indonesia

Ruanni Tupas, National Institute of Education, Singapore (ScopusID: 57126426900)

Santosh Kumar Behera, Sidho-Kanho-Birsha University, India

Shu-Chuan Chen, Asia University, Taiwan

Stephanus Mangga, Gadjah Mada University, Indonesia

Sugeng Purwanto, Universitas STIKUBANK, Indonesia

Zane Goebel, Latrobe University, Australia (ScopusID: 18835285000)

\section{Assistant Editors:}

Galang Fajaryanto, Diponegoro University, Indonesia

Moh Khoirul Anam, Diponegoro University, Indonesia

Muh. Ahlis Ahwan, Diponegoro University, Indonesia

\section{Editorial Offices:}

Master Program in Linguistics, Faculty of Humanities, Diponegoro University Addreses: Jalan Prof. Sudharto, Tembalang, Semarang, Indonesia, Pos Code: 50275 Phone: 024-76480619 |E-mail: parole@live.undip.ac.id 


\section{Parole Journal of Linguistics and Education}

Volume 8 Number 2 October 2018

Available online at: http://ejournal.undip.ac.id/index.php/parole

\section{Table of Contents}

Grammatical Errors in English for Office BLK Instructional Materials

Konstantinus Kapu, Endah Dewi Muliandari, Deli Nirmala

Page 46-51

Problematics of Technical Preparation and Constraints in the Spelling System of Madurese Language Ali Badrudin, Akhmad Sofyan

Page 52-56

The Use of Speech Level in Socio Cultural Perspetive of Tapal Kuda Madurese Ethnic Society Akhmad Haryono, Bambang Wibisono

Page 57-65

EFL Prospective Teacher Educators' Beliefs towards the Use of WhatsApp in English Learning and Teaching Jepri Ali Saiful

Page 66-71

Narrative Writing on New Immigrant Women: Perspective on Cultural Identity and Mother-Daughter Relationship

Shu-Chuan Chen, Chih-Hui Fang

Page $72-80$ 


\section{Editor's Notes}

In this volume, as journal in linguistics and education, Parole presents five topics relevant to macro linguistics namely language teaching material development, standardized spelling system of Madurese language, speech level in Tapal Kuda Madurese ethnic society, teacher's belief toward the use of Whatsapp in English learning and teaching, and narrative writing on new immigrant women.

More specifically, the topics can be explained as follows. First, Konstantinus Kapu, Endah Dewi Muliandari, and Deli Nirmala thought that language instructional materials should be written correctly in terms of content and language. However, they found grammatical errors, inter-language issues, and ambiguity in the instructional materials provided by BLK (Balai Latihan Kerja or Vocational and Education Training Center) to teach English for Offices for trainees at BLK Kajen, Pekalongan, Indonesia. Second, Ali Badrudin and Akhmad Sofyan investigated some problematic issues in Madurese language spelling standardization. There are two versions namely 2003 and 2012 spelling systems. The 2012 version as the revised version of the 2003, according to the users, the system is difficult to implement. Next, Akhmad Haryono and Bambang Wibisono conducted research on speech level in Tapal Kuda Madurese Ethnic society. Fourth, Jepri Ali Syaiful wrote about teacher's beliefs towards the use of WhatsApp in English learning and teaching. Fifth, Shu-Chuan Chen and Chih-Hui Fang wrote about narrative writing on new immigrant women that can show cultural identity of the society.

Last but not least, the editorial team would like to express our gratitude to the Dean of the Faculty of Humanities, Head of Linguistic Department, Faculty of Humanities, Diponegoro University for funding the organizational process of this journal in order that Parole can be published. To all contributors, on behalf of the team, I would like to express our thanks for submitting the article to Parole. In addition, I would like to express our gratitude to all the reviewers and assistant editors, Galang Fajaryanto, Moh Khoirul Anam, and Muh. Ahlis Ahwan for making this journal published.

Semarang, 2 January 2019

Editor in Chief,

Dr. Deli Nirmala, M.Hum. 